REVIEW ARTICLE

J. Food Sci. Technol. Nepal, Vol. 8 (1-11 ) 2013

ISSN: 1816-0727

\title{
Histamine in Foods: Its Safety and Human Health Implications
}

\author{
KRISHNA PRASAD RAI*, HARE RAM PRADHAN, BAL KUMARI SHARMA and SOM KANTA RIJAL \\ Department of Food Technology and Quality Control, Babarmahal, Nepal
}

*Corresponding author: raikrishna1@gmail.com

This article reviews the overall aspects of histamine, one of the most potent biogenic amine, which is formed by decarboxylation of histidine protein rich foods in fish and fish products, dairy products, meat and meat products, fermented vegetables and soy products, and alcoholic beverages such as wine and beer. Normally, three basic conditions i.e. high content of free histidine, bacterial histidine decarboxylase activity and high temperature storage environment elevates the level of histamine in foods. Several chromatographic methods utilizing thin layer chromatography (TLC), high performance liquid chromatography (HPLC), gas chromatography (GC) and colorimetry, fluorimetry and ELISA technique have been developed for the analysis of biogenic amine including histamine. Histamine usually exceeding $1000 \mathrm{mg} / \mathrm{kg}$ has been implicated with scombrotoxicosis. Several government authorities including Codex Alimentarious Commission has also set the level of histamine in different food products varying from 5 to $40 \mathrm{mg} / 100 \mathrm{~g}$. Proper technical regulations and surveillance mechanism as well as hygienic and bio-technological advancement in food manufacturing establishment could be the good preventive measures of low histamine foods in future.

Key words: Histamine, fish, scombrotoxin, Nepalese perspective, safety

\section{Introduction}

Histamine is a common and most important bioactive amine occurring in different foods and beverages. It is generally formed by decarboxylation reaction during which alpha carbonyl group is removed from free amino acid histidine. In addition to its well-known occurrence and important role as a regulator of some human physiological processes, histamine occurs in many different foods and beverages, although their concentrations vary extensively not only between different food varieties but also within the varieties themselves. In spite of being considered as endogenous to certain foods, such as some fruits and vegetables, histamine in foods normally is formed as a result of non-controlled microbial action (Halász et al., 1994). Foods likely to contain elevated levels of histamine include fish and fish products, dairy products, meat and meat products, fermented vegetables and soy products, and alcoholic beverages such as wine and beer (Shalaby, 1996).

Histamine is a naturally occurring substance in mammalian physiology. It is contained in mast cells and basophils, and its biological effects are usually seen only when it is released in large amounts in the course of allergic and other reactions. Histamine exerts its effects by binding to receptors on cellular membranes in the respiratory, cardiovascular, gastrointestinal, haematological, immunological systems and the skin
(Cavanah and Casale, 1993).

Histamine like other biogenic amines is of concern in relation to human health since it is responsible for several toxicological symptoms such as pseudo-allergic reactions (histaminic intoxication), food-induced migraines, and hypertensive crisis due to the interaction between monoamines and monoamine-oxidase inhibitor drugs. Normally, there is no hazard for a healthy consumer, whose monoamino and diaminooxidases will carry out the catabolism of biogenic amines. However, toxicological reactions may occur after the intake of food containing relatively large amounts of histamine (Bodmer et al., 1999). Histamine intolerance results from buildup of histamine in the system that causes a series of toxic effects similar to a common food allergy such as swelling, rashes, hives and asthma-like symptoms as well as gastrointestinal symptoms (Maintz and Novak, 2007).

\section{Structure and Physiological Functions of Histamine}

Chemically, histamine is a 4-(2-aminoethyl) imidazole and is a primary amine arising from the decarboxylation of the amino acid L-histidine. The imidazole ring has two nitrogen atoms. Besides, histamine has two basic center, namely the aliphatic amino group and the nitrogen atom of the imidazole ring which does not already have a proton. Under physiological conditions, the aliphatic amino group (having a $\mathrm{pK}_{\mathrm{a}}$ around 9.4) will be 
Rai et al.: J. Food Sci. Technol. Nepal, Vol. 8 (1-11 ), 2013

protonated, whereas the second nitrogen of the imidazole ring (having a $\mathrm{pK}_{\mathrm{a}} \approx 5.8$ ) will not be protonated. Thus, histamine is normally protonated to a singly charged cation (Paiva et al., 1970).

Endogenous histamine plays important roles in a number of normal and abnormal biological processes like vasodilatation, anaphylaxis, neurotransmission and gastric secretion (Joosten, 1988; Shalaby, 1996). Histamine possesses a powerful biological function, serving as a primary mediator of the immediate symptoms noted in allergic responses (Taylor, 1986). It is a powerful vasodilator in animal tissues and it also stimulates acid secretion in the stomach. A growing array of pharmaceutical agents is being designed to interfere with either the synthesis or the action of histamine. A prominent example is the histamine receptor antagonist Cimetidine (Tagamet), a structural analog of histamine. It promotes the healing of duodenal ulcers by inhibiting secretion of gastric acid (Lehninger et al., 2004).

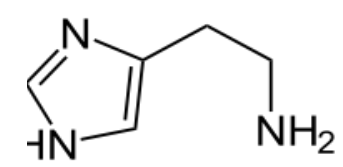

Figure 1. Molecular structure of histamine (Lehninger et al., 2004)

\section{Biosynthesis and Metabolism of Histamine}

Numerous bacteria and some yeast are reported to express histidine decarboxylase activity, thus having the capacity to form histamine (Halász et al., 1994; Straub et al., 1995). Pre-requisites for the undesired formation of histamine by microorganisms in foods are availability of free amino acid histidine, presence of decarboxylase active microorganisms, and favorable conditions for decarboxylation of amino acids. Among the bacteria are several species of the genera Bacillus, Clostridium, Enterobacter, Escherichia, Lactobacillus, Pediococcus, Proteus, Pseudomonas, and Salmonella (Bodmer et al., 1999). Likewise, Zygoascus hellenicus var. hellenicus is a yeast capable of producing histamine in wine (Chang et al., 2009). There is good evidence that in processed (fermented) foods, the contaminating microflora rather than the starter cultures is responsible for the generation of increasing histamine levels (Teuber, 1993). Nevertheless, in microbial food processing, all starter culture candidates (e. g. strains of Lactobacillus) should also be carefully checked for their potential of histamine formation, under the appropriate processing conditions, and only strains with no or low histamine formation capacity should be selected for production purposes. Microbial strains with high proteolytic enzyme activity also potentially increase the risk for histamine formation in food systems, by increasing the availability of free histidine (Suzzi and Gardini, 2003).

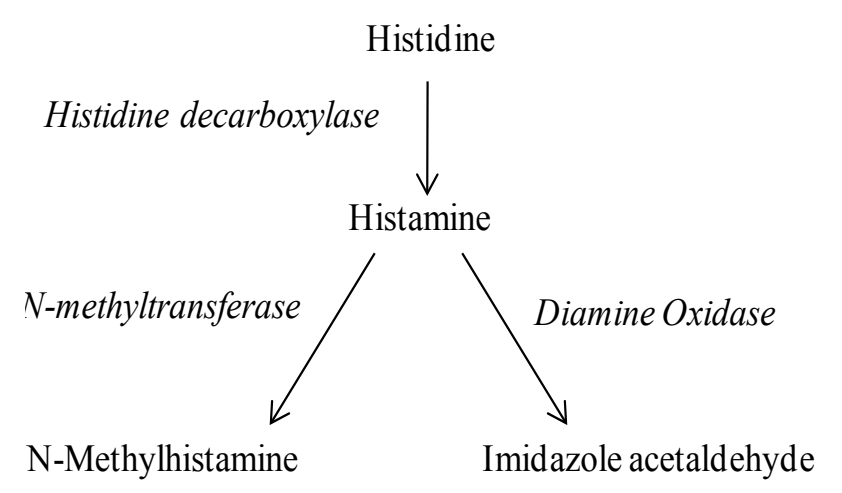

Figure 2. Biosynthesis and catabolism of histamine

According to Shalaby (1996), among microorganism found in meat products, histamine was produced by Hafnia alvei, Klebsiella oxytoca, Morganella morganii, Edwardsiella spp. as well as lactic acid bacteria such as Lactobacillus brevis, L. buchneri, L. divergens, L. carnis, L. curvatus and L. hilgardii. However, some sausage samples contained histamine levels of about $50 \mathrm{mg} / \mathrm{kg}$ and also high levels of amines that can potentiate the toxicity of histamine. Therefore, these samples could cause histamine intoxication in sensitive individuals (Taylor, 1985).

Histamine can be catabolized by several routes. It can be oxidatively deaminated by diamine oxidase (DAO, or histaminase) to imidazole acetaldehyde (and imidazoleacetic acid) as well as methylated by histamine methyl transferase (HMT) to form methylhistamine or its side chain can be methylated or acetylated tyramine (Rice et al., 1976; Taylor, 1986). Monoamine oxidase (MAO) is also important in histamine metabolism (Taylor, 1986).

Normally, low amount of biogenic amines including histamine are metabolized to physiologically less active degradation products during the food intake process in the human gut. This detoxification system includes specific enzymes (e.g. monoamine oxidase MAO, diamine oxidase DAO). However, upon intake of high loads of biogenic amines with foods, this detoxification system is unable to eliminate biogenic amines sufficiently. Moreover, in case of insufficient DAO-activity, caused by e. g. genetic predisposition, gastrointestinal diseases, or inhibition of DAO-activity due to secondary effects of medicines or alcohol, already low amounts of biogenic amines cannot be metabolized efficiently. If detoxification is inefficient, 
biogenic amines are readily absorbed and get into systemic circulation, leading to toxic effects (Bodmer et al., 1999). However, high histamine consumption causes life threatening intoxication; lower amounts can lead to headache, nausea, hot flushes, skin rashes, sweating, and respiratory distress, cardiac and intestinal problems (Bodmer et al., 1999). Histamine at levels usually exceeding $1000 \mathrm{mg} / \mathrm{kg}$ has been implicated with certain food intoxications such as scombrotoxicosis (Taylor et al., 1984) or the "cheese syndrome" (Taylor et al., 1982).

\section{Occurrence of Histamine in Foods}

Histamine presence is common to most fermented fruits and vegetables products, meats, fish, cheese, and other proteineous food material containing high level of histidine amino acid. One of the major sources of histamine is fish, accounting $8 \%$ for tuna species among globally traded fishes (FAO, 2014). Table 1 summarizes the list of food materials in which histamine was traced at a significant level.

\section{Toxic Effects and Histamine Poisoning}

Histamine usually exceeding $1000 \mathrm{mg} / \mathrm{kg}$ has been implicated with certain food intoxications such as

Table 1. Occurrence of histamine in different foods

\begin{tabular}{lll}
\hline Foods & Histamine level (mg/kg) & Reference \\
\hline Japanese sardine fish sauce & $1500 \pm 30$ & Kuda and Miyawaki, \\
Chub mackerel & $1480 \pm 10$ & 2010 \\
Dried fish products, Taiwan & $63.1-479.0$ & Huang et al., (2010) \\
Cheese & 100 & Aygun et al., (1999) \\
Frozen fish & $10-267$ & \\
Fresh fish & Trace & Hwang et al., (2003) \\
Shrimp & Trace & \\
Fish products & Trace to 26 & \\
Fish products of Fiji & $*$ ND to 64 & \\
Fish products of Thailand & ND to 143 & Tao et al., (2011) \\
Fish products of Combodia & 53 to 148 & \\
Fish products of Philipine & 19 to 1530 & Tang et al., (2011) \\
Sufu fermented soyabean foods & 18.2 & Ekici et al., (2004) \\
Fermented sausage & $19.64-87.47$ & Lu et al., (2009) \\
Chinese soya sauces & N.D. to 592 & Hu et al., (2007) \\
Fermented silver carp sausages & $38.22-46.18$ & Shakila et al., (2003) \\
Indian mackerel & 162 & Tsai et al., (2005) \\
Supermarket Kimchi, Taiwan & ND to 535 & Auerswald et al., (2006) \\
Processed sea foods, Dried tuna & 8001 & Claeys et al., (2009) \\
Fish in Greek & 2.7 to 220 & Tsai et al., (2005) \\
Kimchi, Taiwan & $<4.9$ to $>100$ & Kung et al., (2007) \\
Miso products, Taiwan & N.D. to 21.6 & \\
Fresh seafoods & $0-9$ & Auerswald et al., (2006) \\
Processed seafoods & $0-3$ & \\
Dried tuna & 800 & \\
*N.D. Not detected below 7mg/kg & &
\end{tabular}

scombrotoxicosis (Taylor et al., 1984) or the "cheese syndrome" (Taylor et al., 1982). Askar and Treptow (1993) indicated that histamine at a concentration of $500 \mathrm{mg} / \mathrm{kg}$ in food to be hazardous for human health. Normally, three pre-conditions can elevate the postmortem histamine concentration in fish: (1) a sufficiently high content of free histidine, (2) the presence of bacterial histidine decarboxylase, and (3) environmental conditions, such as high temperature (Lehane and Olley, 2000).
Scombrotoxic fish poisoning also known as scombroid or histamine fish poisoning is a common illness associated with seafood which is caused by bacterial spoilage of certain finfish such as tuna, mahi-mahi, bluefish, mackerel, bonito, which is rich in histidine amino acid. As bacteria break down fish proteins, byproducts such as histamine and other substances that block histamine breakdown build up in fish. Eating of spoiled fish that have high levels of these histamines can cause in 


\section{Rai et al.: J. Food Sci. Technol. Nepal, Vol. 8 (1-11 ), 2013}

human disease. Symptoms begin within ten minutes to four hours after consuming contaminated fish. Initial symptoms suggest an allergic response with facial flushing and sweating, burning-peppery taste sensations about the mouth and throat, dizziness, palpitations, nausea and headache. These initial symptoms can advance to facial rash, hives, edema, short term diarrhea and abdominal cramps. Severe cases may cause blurred vision, respiratory stress and swelling of the tongue. Symptoms usually last for approximately four to six hours and rarely exceed one to two days. Treatment is generally unnecessary, but antihistamines or epinephrine may be needed in certain instances. Symptoms may be more severe in patients taking certain medications that slow the breakdown of histamine by their liver, such as isoniazide and doxycycline (CDC, 2000).

Cheeses with high histamine levels have also been associated with outbreaks of histamine poisoning. The types of cheese incriminated include Swiss, Gouda, Gruyere, Parmesan and Provolone among others (Bean et al., 1997; Vale \& Gloria, 1998). The symptoms associated with intoxication include hypotension, nausea, vomiting, abdominal pain, diarrhea, facial flushing, burning throat, thirst, lip swelling, edema, localized inflammation, rash, itchiness and palpitation. Putrescine and cadaverine, also found in cheese, can increase histamine toxicity, facilitating its passage through the intestinal barrier (Chang et al., 1985).

Histamine exerts its toxicity by interacting with the receptors on cellular membranes. There are three types of histamine receptors, $\mathrm{H}_{1}, \mathrm{H}_{2}$ and $\mathrm{H}_{3}$ (Cavanah and Casale, 1993). The most common symptoms result from action on the cardiovascular system. Histamine causes dilatation of peripheral blood vessels, causing urticaria, hypotension, flushing and headache. Histamine-induced contraction of intestinal smooth muscle causes abdominal cramps, diarrhoee and vomiting. Pain and itching associated with the urticarial lesions may be due to sensory and motor neuron stimulation (Taylor, 1986). Gastric acid secretion is regulated by histamine through $\mathrm{H}_{2}$ receptors located on the parietal cells (Soll and Wollin, 1977), but is unknown whether this action accounts for some of the symptoms observed in cases of histamine poisoning (Taylor, 1986).

A fairly efficient detoxification system exists in the intestinal tract of mammals (including humans), which is capable of metaboloshing normal dietary intakes of biogenic amines. The enzymes monoamine oxidase (MAO) and diamine oxidase (DAO) play an important role in this detoxification process. However, upon intake of high loads of biogenic amines with foods, this detoxification system is unable to eliminate biogenic amines sufficiently (Wendakoon and Sakaguchi, 1993). Moreover, in case of insufficient DAO-activity, caused by e. g. genetic predisposition, gastrointestinal diseases, or inhibition of DAO-activity due to secondary effects of medicines or alcohol, already low amounts of biogenic amines cannot be metabolized efficiently. If detoxification is inefficient, biogenic amines are readily absorbed and get into systemic circulation, leading to toxic effects (Sattler et al., 1985; Götz et al., 1996). According to Maijala \& Eerola (1993) the toxic limits of histamine at levels of $8 \pm 40 \mathrm{mg}, 40 \pm 100 \mathrm{mg}$ and over $100 \mathrm{mg}$ may cause slight, intermediate and intensive poisoning, respectively. Putrescine, cadaverine and agmatine have been identified as potentiators that enhance the toxicity of histamine to humans by depressing histamine oxidation (Taylor, 1986). Besides DAO, monoamine oxidases (MAO) distributed in different tissues of the human body also participates in the physiological inactivation of biogenic amines. Again, certain drugs (MAO-inhibitors) are well known to decrease the activity of MAO, leading to an increased risk for pathophysiological processes after intake of food contaminated with biogenic amines.

The toxicological level of a particular amine depends among other things on the ability of detoxification system of the intestinal tract and on the presence of other amines, and is therefore very difficult to establish. A limit $100 \mathrm{mg}$ histamine $/ \mathrm{kg}$ food was suggested. An ingestion of 100 $\mathrm{mg}$ of histamine or $10-100 \mathrm{mg}$ of tyramine can cause poisoning (Eerola, Roig-Sagues, \& Hirvi, 1998).

Histamine poisoning is intoxication, so the incubation period is rather short, ranging from several minutes to a few hours after ingestion of the contaminated fish. The duration of the illness is usually short also; symptoms subside within a few hours in most cases. The intoxication is characterized by a wide variety of possible symptoms of cutaneous (rash, urticaria, edema, localized inflammation), gastrointestinal (nausea, vomiting, diarrhea, cramping), hemodynamic (hypotension), and neurological (headache, palpitations, flushing, tingling, burning, itching) nature. The acute symptoms generally are transient, lasting only 8 to 12 hours.

Histamine poisoning is often confused diagnostically with food allergies, because of the similar symptoms and the equivalent effectiveness of antihistamines. However, histamine poisoning can be easily distinguished from food allergy on the basis of (1) the lack of a previous history of allergic reactions to the incriminated food, (2) the high attack rate in group outbreaks, and (3) the detection of high levels of histamine in the incriminated 
food (Taylor, 1986).

Antihistamine therapy is the optimal mode of therapy for histamine poisoning. Symptoms usually subside rapidly after treatment with $\mathrm{H}_{1}$ antagonists, such as diphenhydramine or chlorpheniramine, or $\mathrm{H}_{2}$ antagonists, such as cimetidine. Since the disease is self-limited, pharmacological intervention is generally not required in mild cases.

Moreover, several factors such as alcohol and other amines (diamines putrescine and cadaverine), individual sensitivity, inactivation of detoxification mechanisms due to genetic deficiencies, gastrointestinal diseases or MAOI treatments, potentiate the toxicological effects of histamine (Brink et al., 1990; Marine'-Font et al., 1995). Hence, it is difficult to evaluate the toxicity degree of biogenic amines in food, and thus, to establish toxic threshold levels for these food microcomponents. Formation of carcinogenic nitrosamines constitutes an additional toxicological risk related to biogenic amines, especially in meat products that contain nitrite and nitrate as curing salts (Marine'-Font et al., 1995).

\section{Preventive Measures}

The most frequent foodborne intoxications and intolerances, caused by biogenic amines, involve histamine. The evidence of histamine-related food intoxication (Silla Santos, 1996), histamine-induced food intolerance (Wantke et al., 1993; Götz et al., 1996) and enteral histaminosis (Sattler et al., 1999) clearly represents a challenge for the food industry to produce foods with extremely low histamine levels. Therefore, biogenic amines are of concern in relation to food spoilage, food safety, and food intolerance and their content in foods should be as low as possible. Now, there are several researches focused on minimizing the production of histamine and other biogenic amine formation in foods mainly fish and other shellfish products. Some efforts are summarized in Table 2.

Table 2. Preventive measures for histamine suppression in different food models

\begin{tabular}{llll}
\hline Food model & Particulars & $\begin{array}{l}\text { Use of mixed cultures for } \\
\text { histamine reduction }\end{array}$ & Reference \\
\hline Fish sausage & Histamine & S. xylosus and L. casie & Hu et al., (2007) \\
Dried sausage & Histamine & S. xylosus, P. pentosaseus, L. casie & Gardini et al., (2002) \\
& $\begin{array}{l}\text { Histamine and } \\
\text { other biogenic } \\
\text { aminese style dry }\end{array}$ & $\begin{array}{l}\text { S. xylosus, } \\
\text { Permented sausage }\end{array}$ & Rai, (2005) \\
Fish sauce & Histamine & 20\% (w/v) nuka-paste & \\
\hline
\end{tabular}

Apart from these, the following tools can be implementing to minimize the risk of such contaminants in foods.

- Legal regulation of S. xylosus

- Implementation of GMP, GHP, HACCP

- Good surveillance and monitoring of histamine in fish and other fermented foods.

- Export import certification to marine foods

Apart from these, some microbiological antagonistic technique has been successfully reported to control the histamine production in meat products (Table 2).

Evidently, foods or raw materials rich in free histidine, such as some fish species (scombroid fish, herring, and anchovies) are potentially more jeopardized to contain high histamine levels. Moreover, the level of free histidine in fish and fishery products even increases during storage, due to the action of endogenous and contaminating proteases. Therefore, in order to keep histamine levels in fish and fish products as low as possible, both proteolytic and decarboxylation activities must be inhibited immediately after the catch. Several studies clearly show that immediate storage on ice drastically decreases the rate of histamine formation, although not completely inhibiting it (Lehane and Olley, 2000).

\section{Low Histamine Technology}

Free histidine liberated through proteolysis is the main precursor of histamine. In general, results from numerous investigations demonstrate that high histamine contents in most foods and beverages mainly result from microbiological contamination. Normally, the presence and composition of free amino acids in a certain foodstuff cannot be changed without major changes of 
Rai et al.: J. Food Sci. Technol. Nepal, Vol. 8 (1-11 ), 2013

its taste, flavour and nutritional value. Therefore, state of the art technology must focus on complete lack of unwanted, decarboxylase-active microorganisms, and/or use of process conditions that do not allow amino acid decarboxylases to be active (FDA, 1998). Since biogenic amines may exert synergistic effects and compete for detoxification by DAO, food producers should optimize their technology to guarantee low levels for all biogenic amines in their products (Bodmer et al., 1999).

Although every food variety requires special precautions and technology (HACCP concept), there are a few common parameters which can be defined for lowhistamine technology. First, high quality raw materials, free of histamine, must be used. Additionally, proper and careful treatment (harvest, transport, storage) of raw materials until processing is absolutely necessary. Growth and activity of decarboxylasepositive microorganisms (spoilage microbes) must be avoided, and activity of endogenous proteases and amino acid decarboxylases have to be inhibited. This can be achieved by technological measures (removal of endogenous microflora) and proper and hygienic production conditions (cooling, freezing, salting etc.) If microbial transformations such as alcoholic or other fermentations are part of the production process, use of specifically selected starter cultures for these fermentations is important, as well as strict control of the whole fermentation process. Activity of foodborne decarboxylases and unwanted microbial activity must be suppressed, while fermentation is performed under strict control by selected, decarboxylase negative starter cultures. Finally, the whole production process should be embedded in a specific quality control procedure and quality management system, including analytical control at critical points (Hungerford et al., 1997; Bodmer et al., 1999).

Practically histamine-free, premium quality products not only are of major importance to all modern consumers, but also allow the growing number of individuals at risk a more diversified nutrition. Therefore, low-histamine technology can help to make safety food products.

\section{Legal Standard and Safety Level for Histamine}

FDA (1998) guidelines for tuna, mahi-mahi and related fish specified $50 \mathrm{mg} / 100 \mathrm{~g}$ as the toxicity level and 5 $\mathrm{mg} / 100 \mathrm{~g}$ as the defect action level because histamine is not uniformly distributed in a decomposed fish. Similarly, European Union Directive No. 91/493 stipulated that nine independent samples from each batch should correspond to: (1) an average histamine concentration lower than $10 \mathrm{mg} / 100 \mathrm{~g}$, (2) no more than two samples out of nine with a concentration of between 10 and 20 $\mathrm{mg} / 100 \mathrm{~g}$ and (3) no sample with a histamine content higher than $20 \mathrm{mg} / 100 \mathrm{~g}$. The limits imposed by these regulatory agencies have been taken into consideration for developing the color scale. The color intensity range of $0-50 \mu \mathrm{g} / \mathrm{ml}$ of histamine works well with the color scale and the spectrophotometric absorbance too (Patange et al., 2005).

The critical dose of oral histamine has been estimated to be in the range of 100-200 mg (Luthy and Schlatter, 1983; Treptow and Askar, 1996). In rats, the noobserved adverse effect level for tyramine, putrescine, and cadaverine was reported to be at $180 \mathrm{mg} / \mathrm{kg}$ of body weight and day (Til et al., 1997). However, some regulatory standards for histamine in different foods are presented in Table 3.

\section{Histamine in Nepalese Perspective}

Altogether 53 samples of Rohu (Labeo rohita) were collected from different markets of Nepal. The analytical results have been shown in Table 4. All fish samples showed histamine in the range of ND to $10.40 \mathrm{mg} / 100 \mathrm{~g}$. The highest concentration range was ND to $10.4 \mathrm{mg} /$ $\mathrm{kg}$ found in Biratnagar and Birgunj samples, while the lowest concentration of histamine was found in samples collected from Bhairahawa $0.13-0.39 \mathrm{mg} / 100 \mathrm{~g}$.

Table 3. Legal standard for histamine in different countries and organizations

\begin{tabular}{lll}
\hline Food & Standard & Reference \\
\hline Fish sauce & $40 \mathrm{mg} / 100 \mathrm{~g}$ & CODEX STAN 302(2011) \\
Sardine fish, Tuna & $20 \mathrm{mg} / 100 \mathrm{~g}$ & CODEX STAN 94 - 1981, CODEX STAN 70-1981 \\
Sea foods & $200 \mathrm{ppm}$ & Australian Food Standards Code, 2001 \\
Sea foods & $100 \mathrm{ppm}$ & EC, 2003 \\
Sea foods & $50 \mathrm{ppm}$ & USA (FDA, 1998) \\
Sea foods & $100 \mathrm{ppm}$ & South African Bureau of Standards, 2001 \\
Edible fresh fish & $5 \mathrm{mg} / 100 \mathrm{~g}$ & FDA, 1998 \\
Fish & $10 \mathrm{mg} / 100 \mathrm{~g}$ & Canada Standard \\
\hline
\end{tabular}


Rai et al.: J. Food Sci. Technol. Nepal, Vol. 8 (1-11 ), 2013

The highest mean for histamine concentration in fish samples was found as $4.18 \mathrm{mg} / \mathrm{kg}$ bought from Biratnagar and Birgunj showed the highest amount of histamine (mean: $4.19 \mathrm{mg} / 100 \mathrm{~g}$ ), while the lowest concentration mean was found in Kathmandu samples i.e. $0.25 \mathrm{mg} / 100 \mathrm{~g}$. Additionally, $9.43 \%$ of fish samples were found out of US FDA standard i.e. within $5 \mathrm{mg} / 100 \mathrm{~g}$. Mainly, samples collected from Biratnagar wand Birgunj was found higher level of histamine i.e. 4 out of 11 samples. None of the samples were found out of standard for Kathmandu, Lalipur and Bhairahawa. The region could be good storage practices in such cities as well as Bhairahawa is a main custom point to enter the fish from India. However, the quantity trace to more than $800 \mathrm{mg} / \mathrm{kg}$ has been determined in different food samples in world markets (Table 1). This finding showed that the fish selling in Nepalese markets are not all fresh and histamine was detected in higher level in samples sold in tropical area such as Biratnagar, Birgunj etc.

\section{Analytical Technique}

The AOAC procedure is an official method for analyzing histamine in foods in the USA. According to this procedure, the food sample is homogenized with methanol, filtered, and then applied to an anion exchange column prior to derivatization with o-phthaldehyde. The fluorescence of the resulting compound is then measured by numerous chromatographic methods utilizing thin layer chromatography (TLC), high performance liquid chromatography (HPLC), colorimetry, fluorimetry, ELISA technique and gas chromatography (GC) techniques have been developed.

Several authentic research papers and standard methods have been developed for the analysis of Histamine in food products, which are summarized in Table 5.

Table 4. Histamine determined in different fish sample sold in Nepalese markets

\begin{tabular}{|c|c|c|c|c|}
\hline Particulars & Places & Total No of samples & Mean \pm SD & Percentage for out of standard \\
\hline Flesh & Kakarvitta & 10 & $3.51 \pm 2.47$ & 10 \\
\hline Flesh & Bhairahawa & 10 & $0.28 \pm 0.08$ & 0 \\
\hline Flesh & Kathmandu & 11 & $0.25 \pm 0.02$ & 0 \\
\hline Flesh & $\begin{array}{l}\text { Biratnagar } \\
\text { and Birguni }\end{array}$ & 11 & $4.18 \pm 3.79$ & 36.36 \\
\hline Flesh & Lalitpur & 11 & $1.49 \pm 0.52$ & 0 \\
\hline
\end{tabular}

Source: Rai et al. (2012)

\section{Further Scopes and Research Needs}

Although much is known about Histamine Poisoning in food, there are still many gaps in our knowledge. Sufficient data are not available at this stage in the country for an adequate risk characterization and thus risk assessment. Further strategies for risk management and risk communication can be put on place only after additional data are generated and analysed. Further, regulatory action may need to take into account the impact of potentiators, and the identification of such substances in various foods. When analyzing suspect fish for histamine, the simultaneous detection of other common putrefactive amines such as cadaverine and putrescine could be advantageous. The mechanism of toxicity of Histamine Poisoning is still not clearly understood, which is unsatisfactory. More research is needed to determine the role that potentiators or ohtter toxins may play in causing the disease. It is particularly important that Histamine Fish poisoning be clearly differentiated from syndromes caused by endogenous toxins such as ciguatoxins that may be present in finfish from time to time. More research still needs to be done on post harvest contamination in order to improve quality control procedures. Identification of points at which temperatures specific bacterial contamination would occur leading to histamine formation needs to be researched where this has not been done already, on harvesting, transporting, storage, processing and retailing practices for those foods most likely to cause histamine poisoning. A study of the correlation between the amine content and the bacterial counts needs to be done. Ideally, each amine would be correlated with its respective amine-producing bacteria. Government regulatory agencies require the removal of histamine contaminated food products from the market place and should established mechanisms to allow efficient and complete trace back of incriminated fish to the point of origin. Furthermore, there is a need for global standardization of histamine detection methods, laboratory accreditation and proficiency testing. A rapid and cheap assay for detecting histamine in contaminated food items (like meat, fish and cheese) should be developed.

\section{Conclusions}

Excess level of histamine in foods and beverages may cause histamine poisoning for human. Histamine does 
Rai et al.: J. Food Sci. Technol. Nepal, Vol. 8 (1-11 ), 2013

Table 5. Standard analytical methods for histamine determination

\begin{tabular}{|c|c|c|c|}
\hline Methods & Sensitivity & Application & Reference \\
\hline TLC & $<20 \mathrm{ppb}$ & $\begin{array}{l}\text { Fish and fishery } \\
\text { products }\end{array}$ & $\begin{array}{l}\text { Shalaby, (1996); Shakila et al., } \\
\text { (2001); Zhihua et al., (2011) }\end{array}$ \\
\hline TLC/densitometry & $\begin{array}{l}\mathrm{LOD}=0.7 \mathrm{mg} / \mathrm{L} \\
\mathrm{LOQ}=1.1 \mathrm{mg} / \mathrm{L}\end{array}$ & Wines & Romano et al., (2012) \\
\hline ELISA kits & $2 \mathrm{mg} / \mathrm{kg}$ & Fish & $\begin{array}{l}\text { Aygun et al., (1999); Hungerford } \\
\text { and } \mathrm{Wu},(2012)\end{array}$ \\
\hline HPLC & 5-100ng & $\begin{array}{l}\text { Fish and fishery } \\
\text { products }\end{array}$ & $\begin{array}{l}\text { Shakila et al., (2001); Innocente } \\
\text { et al., (2007) }\end{array}$ \\
\hline $\begin{array}{l}\text { HPLC-FLD and UV } \\
\text { detector }\end{array}$ & $\begin{array}{l}\mathrm{LOD}=1.5 \mathrm{mg} / \mathrm{kg} \\
\mathrm{LOQ}=4.5 \mathrm{mg} / \mathrm{kg}\end{array}$ & Fish samples & Tahmouzi et al., (2011) \\
\hline Colorimetery & $1 \mathrm{mg} / 100 \mathrm{~g}$ & $\begin{array}{l}\text { Fish and fishery } \\
\text { products }\end{array}$ & Patange et al., (2005) \\
\hline Fluorometery & - & Meat products & Ekici et al., (2004) \\
\hline Filter paper electrophoresis & - & Tuna fish & Tao et al., (2009) \\
\hline GC-FID, GC-MS & $5 \mu \mathrm{g} / \mathrm{g}$ & $\begin{array}{l}\text { Fish and fishery } \\
\text { products }\end{array}$ & Hwang et al., (2003) \\
\hline $\begin{array}{l}\text { Ultra-performance liquid } \\
\text { chromatographic (UPLC) } \\
\text { method }\end{array}$ & $\begin{array}{l}0.032 \text { and } 0.098 \\
\mu \mathrm{g} / \mathrm{l} ;\end{array}$ & $\begin{array}{l}\text { pork, beef, chicken } \\
\text { and fish meat, } \\
\text { cheese and edible } \\
\text { mushrooms }\end{array}$ & Dadakova et al., (2009) \\
\hline $\begin{array}{l}\text { Quantitative Food EIA test } \\
\text { kits }\end{array}$ & $1 \mathrm{ppm}$ & $\begin{array}{l}\text { Tuna and other } \\
\text { marine fish products }\end{array}$ & Kose et al., (2011) \\
\hline $\begin{array}{l}\text { Chronopotentiometric } \\
\text { analysis }\end{array}$ & $\begin{array}{l}\text { LOD: } 1.31 \mathrm{mg} / \mathrm{L} \\
\text { LOQ: } 3.54 \mathrm{mg} / \mathrm{L}\end{array}$ & Cheese & Jaroslava and Stojanovic, (2011) \\
\hline $\begin{array}{l}\text { Amino Acid } \\
\text { Analyzer HPLC system }\end{array}$ & - & Sea foods & Auerswald et al., (2006) \\
\hline
\end{tabular}

not effect on organoleptic characteristics; however, it clearly induces the food intolerance in an increasing number of human populations. Therefore, histamine content - and content of other harmful biogenic amines must be limited to the lowest possible level.

In the past 15 years, authorities and producers around the world have become more aware of the need for quality assurance in relation to food as a result of which standards for sea food are increasing and exposure to spoiled seafood and thus Histamine Poisoning is likely to become less prevalent. Consumers are becoming minor food borne illness in world. Litigation following food poisoning incidents is becoming more common, and producers, distributors and restaurants will increasingly be held liable for the quality of the products of the products they handle and sell.

Practically histamine-free, premium quality products not only are of major importance to all modern consumers, but also allow the growing number of individuals at risk a more diversified nutrition. Even though histamine induced food intolerance causes major impairment of life quality to an increasing part of our population, most cases remain undiagnosed or misdiagnosed. Therefore, there is an absolute need for better information of physicians, dieticians and consumers.

So far, only few countries have defect or hazard action levels for histamine in their food regulation, mostly restricted to fish, and these levels do not yet consider the evidence from internal histamine poisoning. Therefore, a proper technical regulations and monitoring mechanism seems to be set up in Nepal. 


\section{Rai et al.: J. Food Sci. Technol. Nepal, Vol. 8 (1-11 ), 2013}

\section{References}

Askar A., and Treptow H. (1993). Amines: Encyclopedia of food science, food technology and nutrition. New York: Academic Press.

Auerswald L., Morren C., Lopata A. L. (2006). Histamine levels in seventeen species of fresh and processed South African seafood. Food Chemistry, 98: 231239.

Aygun O., Schneider E., Scheuer R., Usleber E., Gareis M. and Martlbauer E. (1999). Comparison of ELISA and HPLC for the Determination of Histamine in Cheese. J. Agric. Food Chem., 47: 1961-1964.

Bean N. H., Goulding J. S., Daniels M. T. \& Angulo F. J. (1997). Surveillance for foodborne disease outbreaks - US, 1988-1992. Journal of Food Protection, 60(10), $1265-1286$.

Bodmer S. , Imark C. and Kneubühl M. (1999). Biogenic amines in foods: Histamine and food processing. Inflamm. res. 48, 296-300.

Brink B., Damirik C., Joosten H.M.L.J. and Huis in't Veld J.H.J. (1990). Occurrence and formation of biologically active amines in foods. Int. J. Food Microbiol, 11, 73-84.

Cavanah D.K. and Casale T.B., (1993). Histamine. Cited In "Kaliner, M.A., Metcalfe, D.D. (Eds.), The Mast Cell in Health and Disease, Marcel Dekker, New York, Basel, Hong Kong, pp. 321-342, Chapter 11".

CDC (Centers for Disease Control and Prevention) (2000). Scombroid fish poisoning -Pennsylvania, MMWR, 49, 398-400.

Chang S.C., Lin C.W., Jiang C.M., Chen H.C., Shih M.K., Chen Y.Y. and Tsai Y.H. (2009) Histamine production by bacilli bacteria, acetic bacteria and yeast isolated from fruit wines. Food Science and Technology, 42, 280-285

Chang S.F., Ayres J.W. and Sandine W.E. (1985). Analysis of cheese for histamine, tyramine, tryptamine, histidine, tyrosine and tryptophan. Journal of Dairy Science, 68, 2840-2846.

Claeys W., Vleminckx C., Dubois A., Huyghebaert A., Höfte M., Daenens P. and Schiffers B. (2009). Formaldehyde in cultivated mushrooms: a negligible risk for the consumer. Food Additives \& Contaminants: Part A, 26:9, 1265-1272

Dadakova E., Krizek M., Pelikanova T. (2009). Determination of biogenic amines in foods using ultraperformance liquid chromatography (UPLC). Food Chemistry, 116, 365-370.

Lehninger A.L., Nelson D.L. and Cox M.M. (2004). Principles of Biochemistry. 4th edition, pp 859. Macmillan Publishers, Worth New York.
Eerola H. S., Roig-Sague's A.X. \& Hirvi T. K. (1998). Biogenic amines in Finnish dry sausages. Journal of Food Safety, 18, 127-138.

Ekici K., Sekeroglu R., Sancak Y. C. and Noyan T. (2004). A note on histamine levels in Turkish style fermented sausages. Meat Science, 68: 123-125.

FAO (2014). Food Safety and Quality (Histamine). Accessed at: http://www.fao.org/food/food-safetyquality/a-z-index/histamine/en/.

FDA (1998). FDA and EPA guidance levels. In: Fish and Fishery Products Hazards and Controls Guide, 2nd Edition, Department of Health and Human Services, Public Health Service, Food and Drug Administration, Center for Food Safety and Applied Nutrition, Office of Seafood, Washington DC, pp. 245-248.

Gardini F., Martuscellib M., Crudeleb M.A., Paparellac A. and Suzzi G. (2002). Use of Staphylococcus xylosus as a starter culture in dried sausages: effect on the biogenic amine content. Meat Science, 61, 275-283.

Suzzi G. and Gardini F. (2003). Biogenic amines in dry fermented sausages: a review. International Journal of Food Microbiology, 88, 41- 54.

Götz M, Wantke F, Focke M, Wolf-Abdolvahab S, Jarisch R. Histaminintoleranz and Diaminoxidasemangel (1996). Allergologie, 19: 394-8.

Halász A., Baráth A., Simon-Sarkadi L. and Holzapfel W. (1994). Biogenic amines and their production by microorganisms in food. Trends Food Science Tech; $5,42-9$.

$\mathrm{Hu}$ Yongjin, Xia W. and Liu X. (2007). Changes in biogenic amines in fermented silver carp sausages in oculated with mixed starter cultures. Food Chemistry, 104:188-195.

Huang Y.R., Liu K.J., Hsieh H.S., Hsieh C.H., Hwang D.F., Tsai Y.H. (2010). Histamine level and histamine-forming bacteria in dried fish products sold in Penghu Island of Taiwan. Food Control, 21: 1234-1239.

Hungerford J., Wu W.H. (2012). Comparison study of three rapid test kits for histamine in fish: BiooScientific MaxSignal enzymatic assay, Neogen Veratox ELISA, and the Neogen Reveal Histamine Screening test, Food Control, 25: 448-457.

Hungerford J.M., Manger R., Wekell M., Hollingworth T., (1997). Rapid chemical tests: Laboratory and field screening methods for seafood analysis. In: Martin, R.E., Collette, R.L., Slavin, J.W. (Eds.), Fish Inspection, Quality Control, and HACCP: A Global Focus, Proceedings of the Conference held 19-24 May 1996, Arlington,VA, Technomic, Lancaster, 
Basel, pp. 538-550.

Hwang B.S., Wang J.T. and Choong Y.M. (2003). A rapid gas chromatographic method for the determination of histamine in fish and fish products, Food Chemistry, 82: 329-334.

Innocente N., Biasutti M., Padovese M. and More S. (2007). Determination of biogenic amines in cheese using HPLC technique and direct derivatization of acid extract. Food Chemistry, 101: 1285-1289.

Joosten H.M.L.G. (1988). The biogenic amines content of Dutch cheese and their toxicological significance. Neth. Milk Dairy J., 42, 25- 42.

Köse S., Kaklýkkaya N., Koral S., Tufan B., Buruk K.C. and Aydýn F. (2011). Commercial test kits and the determination of histamine in traditional (ethnic) Fish products-evaluation against an EU accepted HPLC method. Food Chemistry, 125: 1490-1497.

Kuda T. and Miyawaki M. (2010). Reduction of histamine in fish sauces by rice bran nuka. Food Control, 21: 1322-1326.

Kung H.F., Tsai Y.H. and Wei C.I. (2007). Histamine and other biogenic amines and histamine-forming bacteria in miso products. Food Chemistry, 101, 351-356.

Lehane L. and Olley J. (2000). Histamine fish poisoning revisited. International Journal of Food Microbiology, 58, 1-37.

Lu Y., Chen X., Jiang M., Lv X., Nurgul R., Dong M. and Gujun Y., ( 2009). Biogenic amines in Chinese soy sauce. Food Control 20: 593-597.

Luthy J. and Schlatter C. (1983). Biogene Amine in Lebensmitteln: Zur Wirkung von Histamin, Tyramin und Phenylethylamin auf den Menschen (Biogenic amines in foods: effects of histamine, MaxSignal enzymatic assay, Neogen Veratox ELISA, and the Neogen Reveal.

Maintz, L. and Novak, N. (2007). Histamine and histamine intolerance. Am. J. Clin. Nutr., 85(5):1185-1196.

Paiva T.B., Tominaga M. and Paiva A.C.M. (1970). "Ionization of histamine, N-acetylhistamine, and their iodinated derivatives". Journal of Medicinal Chemistry 13 (4): 689-692.

Patange S.B., Mukundan M.K. and Kumar A.K. (2005). A simple and rapid method for colorimetric determination of histamine in fish flesh. Food Control 16: 465-472.

Rai K.P. (2005). Effects of Starter Cultures on the Quality of Dry Fermented Chinese-style Sausage. MS Thesis, Southern Yangtze University, China.

Rai K.P., Pradhan H. and Sharma, B.K. (2012). Study on Formaldehyde (Formalin) residue and Histamine in Rohu (Labeo rohita) available in Nepalese Markets.
Research Report, DFTQC, 2012.

Rice S.L., Eitenmiller R.R. and Koehler P.E. (1976). Biologically active amines in food: a review. J. Milk Food Technol. 39 (5), 353-358.

Sattler J., Hesterberg R., Lorenz W., Schmidt U., Cromback M., and Stahlknecht C.D. (1985). Inhibition of human and canine diamine oxidase by drugs used in an intensive care unit relevance for clinical side effects. Agents Actions ; 16: 91-4.

Sattler J., Klocker J., Merz C., Stalzer B. and Bodmer E. (1999). Disease concept of enteral-induced histaminosis. Inflamm Res.

Shakila R.J., Vasundhara T.S., Kumudavally K.V. (2001). A comparison of the TLC-densitometry and HPLC method for the determination of biogenic amines in fish and fishery products. Food Chemistry, 75: 255259.

Shakila R.J., Vijayalakshmi K. and Jeyasekaran G. (2003). Changes in histamine and volatile amines in six commercially important species of fish of the Thoothukkudi coast of Tamil Nadu, India stored at ambient temperature. Food Chemistry, 82: 347-352,

Shalaby, A.R. (1996). Significance of biogenic amines to food safety and human health. Food Research International, 29(7), 675-690.

Silla Santos M.H. (1996). Biogenic amines: Their importance in foods. Int J Food Microbiol, 29: 213.

Soll A.H. and Wollin A. (1977). The effects of histamine postglanding $\mathrm{E}_{2}$ and secretin on cyclic AMP in separated canine fundic mucosal cells. Gastroenterology, 72, 1166.

Straub B.W., Kircherer M., Schilcher S.M. and Hammes W.P. (1995). The formation of biogenic amines by fermentation organisms. Zschr Lebensm Unters Forsch ; 201, 79-82.

Tang T., Qian K., Shi T., Wang F., Li J., Cao Y. and Hu Q. (2011). Monitoring the contents of biogenic amines in sufu by HPLC with SPE and pre- column derivatization. Food Control, 22: 1203-1208.

Tao Z., Sato M., Han Y., Tan Z., Yamaguchi T. and Nakano T. (2011). A simple and rapid method for histamine analysis in fish and fishery products using ultra-performance liquid chromatography (UPLC). Food Chemistry, 116: 365-370.

Tao Z., Sato M., Yamaguchi T. and Nakano T. (2009). Formation and diffusion mechanism of histamine in the muscle of tuna fish. Food Control 20: 923-926.

Taylor S.L., Hui J.Y. and Lyous D.E. (1984). Toxicology of Scombroid poisoning. In Seafood Toxins. ed. E.P. Ragils, ACS Symp. Ser. 262. Washington DC, p. 417.

Taylor, S.L. (1985). Histamine poisoning associated with fish, cheese and other foods. Genebra: World Health 
Organization.

Taylor, S. L. (1986). Histamine food poisoning: Toxicology and clinical aspects. Critical Review in Toxicology, 17, 91-128.

Taylor, S.L. (1986). Histamine food poisoning, toxicity and clinical aspects. Crit. Rev. Toxicol., 17, 91-128.

Taylor S.L. and Woychik N.A. (1982). Simple medium for assessing quantitative production of histamine by Enterobacteriaceae. J. Food Prot. 45 (8), 747-751.

Teuber M. (1993). Progress in Food Fermentation. vol. 1. In: Benedito de Barber C, Cellar C, Mertinez-Anaya MA, Morell J, editors. Valencia: IATA CSIC, 16-28.

Til H.P., Falke H.E., Prinsen M.K. and Willems M.I. (1997). Acute and subacute toxicity of tyramine, spermidine, spermine, putrescine and cadaverine in rats. Food Chem. Toxicol. 35, (3-4), 337-348.

Treptow H. and Askar A. (1996). Biogene Amine in Lebensmitteln. Fleisch- und Fleischerzeugnisse,
Fisch und Fischerzeugnisse. In: Biogene Amine in der Erna“hrung; Beutling, D., Ed.; Springer: Berlin, Germany, pp 135-154.

Tsai Y.H., Kung H.F., Lin Q.L., Hwang J.H., Cheng S.H. and Wei C.I. (2005). Occurrence of histamine and histamine-forming bacteria in kimchi products in Taiwan. Food Chemistry, 90, 635-641.

Vale S.R. \& Gloria M.B.A. (1998). Biogenic amines in Brazilian cheese. Food Chemistry, 63(3), 343-348.

Wantke F., Götz M. and Jarisch R. (1993). Histaminefree diet: treatment of choice for histamine induced food intolerance and supporting treatment for chronic headaches. Clin Exp Allergy, 23: 982-5.

Wendakoon C.N. and Sakaguchi M. (1993) Combined effects of sodium chloride and clove on growth and biogenic amine formation of Enterobacter aerogenes in Mackerel muscle extract. J. Food Prot., 56, 410413. 